\title{
食品加工業におけるフライ油の加熱劣化 \\ Thermal Deterioration of Edible Oil Used in Food Manufacturing Companies
}

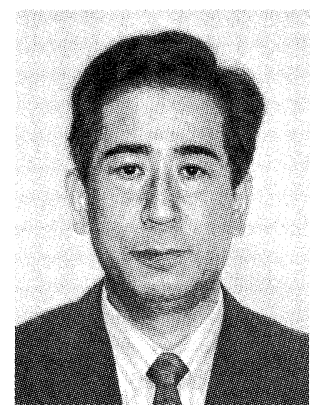

戸谷永生

神戸学院大学栄養学部

T651-2180

神戸市西区伊川谷町有瀬 518

Nagao TOTANI

Faculty of Nutrition, Kobe-Gakuin University

518 Arise, Ikawadani-cho, Nishi-ku, Kobe 651-2180,

JAPAN

論文要旨：食品加工業で使用されるフライ油は，長時間フライ製造のために加熱される結果，フライ油自 体やフライ製品が含有するフライ油の性状が，一般家庭のデイープフライに扔けるフライ油の性状に比較し て劣ることが多い。ここでは使用に伴うフライ油の褐変の原因, 劣化油が生体に与える影響, 食品加工業が 使用後回収された油を脱色して工業用途の油を再生する方法，酸化防止の可能性について概説したのち，食 物連鎖と環境保全の観点から食品加工業用フライ油の使用時間の短縮を提案した。

\begin{abstract}
In food manufacturing companies frying oil is heated for extended hours for production of the deep-fried foods so that properties of the oil itself and of oil contained in the foods are often inferior to those in home deep-frying. This paper describes the mechanism of browning in frying oil, effects of deteriorated oil on health, a method for reclaiming as industrial oil, the oil recovered from food manufacturing companies after use, and possibility of antioxidation during frying, then proposed to shorten the heating time for one batch of frying oil at food manufacturing companies from the viewpoint of food chain and environmental preservation.
\end{abstract}

Key words: Edible Oil, Deep-frying, Thermal Deterioration, Polar Compounds, Color, Amino Acid, Reclamation

\section{1 はじめに}

日本国内では年間約 250 万トンの食用油が消費されて いる ${ }^{1)}$ 。その半分は食品加工業によって使用され，その うちの約 50 万トンがレンダラー, 廃油回収業者等によ り回収されていると推定されている。回収された油のう ち品質のよいフライ油は 20 万トン程度で, 簡単な処理 後, 動物飼料 $(70 \%)$, ペイント・インク・脂肪酸原料 $(20 \%)$ ，燃料・輸出・その他 $(10 \%)$ として再利用され ている ${ }^{2-4)}$ 。換言すると, 食品加工業で使用後, 回収され たフライ油の 40\%は再利用されているが，60\%は再利 用不能なほど劣化が進行しているため焼却処理されてい る。このことより劣化の進んだ廃食用油の処理が環境問
題に繋がる危険性が指摘されている。

消費される食用油の残る半分は一般家庭で使用されて いる。現在, 日本の一般家庭でフライ油は通常, 数回使 用されたのち廃充されるため，その劣化した油による健 康被害の発生は考えにくいが，使用済み油が下水や土中 に廃棄されている，あるいは食品加工業から回収された 品質の劣る油と同様に焼却されている。家庭で使用した 油の回収・再利用の努力もなされているが，この廃油を 回収することは非常に困難な状沉となっている。

様々な料理に使用される食用油（植物油＋獣脂）のう ち，消費量および健康と環境の面から判断するとフライ 油として使用される食用油が一番重要であろう。また食 用油の劣化のなかで，一番激しい劣化は高温（160〜 $190^{\circ} \mathrm{C}$ ）に曝される揚げ（ディープフライ）時の劣化で ある。重合反応，分解反応と同時に，活発な酸化反応が 
進行し, 活性酸素が特に多不飽和脂肪酸を攻撃して過酸 化物・カルボニル化合物・低級脂肪酸・水酸化物 ・ 炭化 水素が生成する。これらフライ油からの生成物の一部 は, さらに揚げだね由来成分とも反応して油の劣化を進 行させる。

本論文ではフライ油がディープフライに使用される間 に引き起こされる加熱劣化のなかで, とくにフライ油の 着色の原因と, 生体に対する影響, 劣化防止, 回収され たフライ油の脱色方法について述べるとともに環境污染 を低減する方策を提案する。

\section{2 フライ油の加熱劣化}

フライ油としてなたね油，大豆油，カノーラ油，サフ ラワー油，パーム油，オリーブ油，ひまわり油，ブレン ド油（なたね油大豆油など），ラード等が市販されて いる。開封直後の新鮮油は酸価 $(\mathrm{AV})<0.1$, カルボニ 儿価 $(\mathrm{COV})<5$, 過酸化物価 $(\mathrm{POV})<5 \mathrm{meq} / \mathrm{kg}$, 極 性化合物量 $(\mathrm{PC})<5 \%$, 色相ガードナー $(\mathrm{G}) 1$ を示すこ とが多い。市販加工食品の成分規格として食品中の油脂 は $\mathrm{AV} \leqq 3, \mathrm{POV} \leqq 30$ であることが決められている。

\section{$2 \cdot 1$ 加熱による性状変化}

食品加工業で使用後, 回収された油のうち品質のよい ものが物理的に処理して販売されており (回収油), そ の代表的な性状は AV 2〜4, COV 約 10, PC 20〜30\%, G 10〜12，トリアシルグリセロール含量（TG）約 90\%， 含水量 $0.4 \sim 0.6 \%$ でずかに濁っている ${ }^{3)}$ 。 AV, COV, $\mathrm{POV}$ は比較的小さいが, PC と Gの上昇と臭いの劣化は 顕著で，肉眼的には紅茶の色相に近い。

われわれは大学内にある食堂の協力を得て, 厨房で使 用されているフライ油の性状変化を春, 夏, 秋に分けて 追跡した ${ }^{5)}$ 。基本的なフライ業務は, 毎朝 $20 \mathrm{~L}$ のフライ 油を $180^{\circ} \mathrm{C}$ に加熱し $10 ： 00 \sim 13 ： 00$ の間にトンカッ 130 〜 150 個，コロッケ 30 個，エビフライ $20 \sim 30$ 個を揚げ る。業務終了後フライ油をろ過し缶に保存。翌朝新鮮フ ライ油を追加して $20 \mathrm{~L} に し$, 同様のディープフライを 繰り返す。木・金曜日の朝には新鮮フライ油を追加せず に使用し，金曜日の業務終了後には残っているフライ油 を廃棄する。場合によっては同じバッチのフライ油を 2 週間連続して使用していた。毎日業務終了後に分与され たフライ油を速やかに分析した結果, 加熱時間 $15 \mathrm{~h}$ 程 度であれば上記のいずれの性状も概ね問題なく，回収油 のレベルには到達していないことがわかった。また季節 毎の温度や湿度がフライ油に与える影響は認められな かった。さらに調理済みの各種フライ製品（カッ，フラ イ, 天ぷら，コロッケ，唐揚げ，揚げだし豆腐）をスー パー，コンビニエンスストアー, デパート，専門店等か
ら 6 月〜 11 月に購入し ${ }^{5)}$ ，衣に含まれるフライ油を溶媒 抽出し，性状分析を行った。市販加工食品の成分規格を 超えることはほとんどなかったが，回収油の性状レベル に達しているフライ油を含む揚げ製品はかなり存在し た。 AV > 2（回収油の AV の下限值）の製品は対象製 品中 $8 \%, \operatorname{COV}>10$ (同 COV の下限値) は $4 \%$, $\mathrm{PC}>20 \%$ （同 $\mathrm{PC}$ の下限值）は $6 \% ， \mathrm{TG}<93 \%$ （同 TGの上限值）は $22 \%$ となった。この結果を統計的にい うと, 調理済みフライ製品 5 25 品のうち， 1 品は使用 済みの回収油より劣化した油を含んでいる可能性がある ことを意味している。この結果は市販の調理済みフライ 製品に関するものであるが，このほかにフライドチキ ン, フライドポテト, 揚げ麺, 揚げ菓子, さつま揚げ, あげ，がんもどき，厚掦げ，外食や業者製造の弁当のな かのフライ製品などが該当すると思われるので，日常比 較的高い頻度で劣化油を摂取している可能性がある。

この $2 \sim 30$ 年来, 調理済及制菜の消費が急激に増えて きている一方, 劣化フライ油中の PC が高血圧の発症に 媣く関わっているとの報告 $\left.{ }^{6}\right)$ があり注意を要する。色相 の劣化も夥しいが，後述するように衣中のフライ油の褐 変は揚げだねから漏出するアミノ酸量と密接な関係があ るため，色相が悪いことが一概に生体にとって危険かど うかは確定していない。しかしフライ油の褐変と同様の 経路で, 発ガン性・遺伝毒性・発生毒性をもつアクリル アミドが生成するとの報告もある ${ }^{7-10)}$ ため，今後の十分 な検討が必要となる。

\section{$2 \cdot 2$ 加熱褐変の原因}

未使用のフライ油（なた㸚油＋大豆油）を $180^{\circ} \mathrm{C}$ に加 熱したときの粘性率の上昇は, 室温下での通常の自動酸 化の程度に関わらず加熱 $20 \mathrm{~h}$ までは大差なく, 揚げだ ねから漏出するレベルの金属にも影響されないことがわ かった ${ }^{11)}$ 。また新鮮なフライ油を $180^{\circ} \mathrm{C} て ゙ 20 \mathrm{~h}$ 加熱した ときの粘性率と回収油の粘性率が等しくなることから， 食品加工業では見かけ上，フライ油を $20 \mathrm{~h}$ 加熱使用し ていると推定した ${ }^{11)}$ 。フライ油のみを $20 \mathrm{~h}$ 加熱しても $\mathrm{G}$ 4〜8にしか到達しなかったことから, 回収油の色相 $\mathrm{G} \geqq 10$ となるためには他の要因が不可欠であることは 明らかである。そこで，新鮮フライ油に揚げだねから混 入する可能性のある物質を，単独にあるいは組み合わせ て新鮮フライ油に添加し， $180^{\circ} \mathrm{C} て ゙ 20 \mathrm{~h}$ 加熱した。その 結果，Fig. 1 (図中には発色の一番強い Met と弱い Glu が示されている。）のようにアミノ酸が実際にフライ油 に混入する量の範囲で強い着色を示したことから，フラ イ油はアミノ酸により $\mathrm{G} \geqq 10$ に褐変することが示され た。たんぱく質はディープフライ中に大量に油に導入さ れるが，発色係数が小さく，衣に大半が捕捉されてしま 


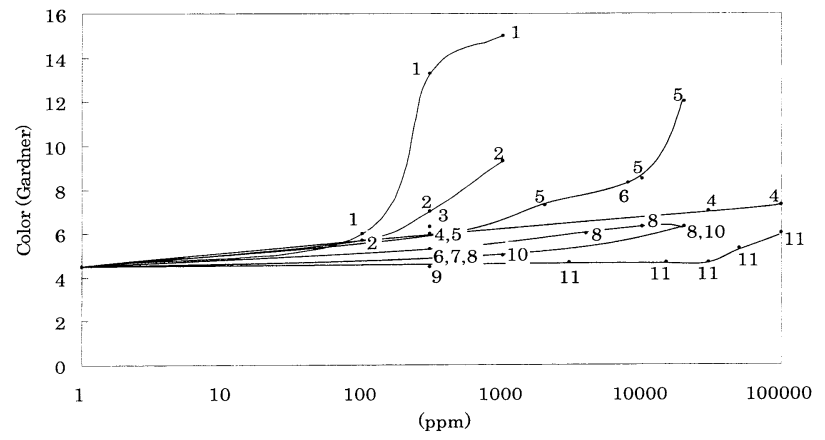

Fig. 1 Color Deterioration of Frying Oil Heated at $180^{\circ} \mathrm{C}$ for $20 \mathrm{~h}$ by Addition of Various Components from Foods. 1 Met; 2 Glu; 3 soy protein; 4 bread crumbs; 5 gluten; 6 milk casein; 7 potato protein; 8 wheat flour; 9 egg albumin; 10 sugar; 11 wheat starch.

う，あるいは油から掬い取られるために強い褐変に結び つかず，澱粉・糖・血液・色素は殆ど褐変とは無関係で あることが示唆された。

さらに $300 \mathrm{ppm}$ の各アミノ酸を新鮮フライ油に添加 し， $180^{\circ} \mathrm{C} て ゙ 20 \mathrm{~h}$ 加熱した（フライモデル実験）ときの 発色について検討した結果, Table 1 のように含硫アミ ノ酸の Cys, Metと, 構造的に不安定な Trp が $20 \mathrm{~h}$ ま での加熱時間に発色しやすく $40 \mathrm{~h}$ 加熱するといずれの アミノ酸も強く発色することが示された。Fig. 1 から理 解されるようにアミノ酸添加量を増加すればさらに強い 発色が見られる。この発色は窒素雲囲気下では現れない (後出) ことから, 酸化油中に存在するカルボニル化合 物とアミノ酸がアミノ・カルボニル反応して褐変物質が 生成すると推察された。

\section{$2 \cdot 3$ 加熱褐変原因物質の検証}

$2 \cdot 2$ においては, ディープフライによってフライ油が 加熱褐変する場合, フライ油自体の加熱着色に加えて揚 げだねから漏出するジュース中に含まれるアミノ酸が着 色を助長していることをフライモデル実験により推定し た。ここではさらに 1 バッチのフライ油において褐変を ひきおこす量のアミノ酸が揚げだねから漏出することを 検証した ${ }^{12)}$ 。まずトンカツや天ぷらなどをディープフラ イしたときの揚げだねの重量減少量を求め, 次にその重 量減少を引き起こすための電子レンジによる加熱条件を 設定した。電子レンジ加熱により得られたジュースにつ いて, ヘキサンによる脱脂・遠心ろ過による分子量 3,000 以上の物質の除去を行ってアミノ酸リッチな画分 を調製した。次いでPTH（phenylthiohydantoin）化し HPLCによるアミノ酸定量分析を実施した。その結果, $100 \mathrm{~g}$ の豚肉・牛肉・鶏肉からそれぞれ計 $88 \mathrm{mg}, 46$ $\mathrm{mg}, 110 \mathrm{mg}$ のアミノ酸がフライ中に漏出することが判 明した。さらに前記画分を凍結乾燥して得られた粉末を 新鮮フライ油に添加して $180{ }^{\circ} \mathrm{C}, 20 \mathrm{~h}$ の加熱実験を行っ
Table 1 Color Deterioration of Frying Oil Containing $300 \mathrm{ppm}$ Amino Acid at $180^{\circ} \mathrm{C}$.

\begin{tabular}{|c|c|c|c|c|c|c|}
\hline \multirow{3}{*}{ Amino acid } & \multicolumn{6}{|c|}{ Color (Gardner) } \\
\hline & \multicolumn{3}{|c|}{ Frying oil ${ }^{*}$} & \multicolumn{3}{|c|}{ Frying oil ** } \\
\hline & $10 \mathrm{~h}$ & $20 \mathrm{~h}$ & $40 \mathrm{~h}$ & $5 \mathrm{~h}$ & $10 \mathrm{~h}$ & $20 \mathrm{~h}$ \\
\hline Gly & $6+$ & 10 & 13 & 5 & 11 & 14 \\
\hline Ala & 6 & 8 & 13 & 4 & 8 & 11 \\
\hline Val & & $8+$ & $13^{-}$ & $8-$ & 14 & $14+$ \\
\hline Leu & & 8 & 12 & 7 & 11 & 13 \\
\hline Ile & & 8 & 12 & $8-$ & 13 & $13+$ \\
\hline Ser & & $8+$ & 13 & 5 & 9 & $11-$ \\
\hline Thr & $7-$ & 10 & 14 & 5 & 10 & 13 \\
\hline Cys & 7 & 11 & 16 & 6 & 10 & $13-$ \\
\hline Met & 8 & $13+$ & 16. & $7+$ & 12 & $14-$ \\
\hline Glu & & 7 & 10 & $4+$ & $5-$ & $8-$ \\
\hline Asp & & $7-$ & 10 & $4+$ & $5-$ & $8-$ \\
\hline Gln & $6+$ & $7+$ & 12 & $5+$ & $6+$ & $10-$ \\
\hline Asn & & 7 & 12 & $4+$ & $6+$ & 10 \\
\hline Lys & $6+$ & 7 & $14+$ & 4 & $11+$ & $13+$ \\
\hline $\operatorname{Arg}$ & & 7 & $12-$ & $6+$ & 11. & $11+$ \\
\hline Phe & $9-$ & $10-$ & 12 & $10+$ & 13 & $15-$ \\
\hline Tyr & & 7 & $12-$ & $4+$ & $6+$ & $10-$ \\
\hline Trp & $13-$ & 13 & $12+$ & $13-$ & 15 & 16 \\
\hline His & & 6 & 13 & $4+$ & 6 & 10 \\
\hline Pro & $7-$ & 8 & 14 & 12 & 12 & $13+$ \\
\hline--- & $4-$ & 4.5 & 6.5 & 4 & $5-$ & 8- \\
\hline
\end{tabular}

* Frying oil added $15 \mathrm{ppm}$ minerals,

** Frying oil added $225 \mathrm{ppm}$ minerals,

- Gardner color $\geqq 11$

た。これより Fig. 2 のように $1 \mathrm{~L}$ のフライ油中で豚カッ や鶏の唐揚げを作る場合, 約 $1 \mathrm{~kg}$ 以上の揚げだねを ディープフライすれば, $20 \mathrm{~h}$ 以内にフライ油の色相が $\mathrm{G} \geqq 10$ となることが示された。フライ衣がアミノ酸の 一部を捕獲するであろうが，1Lのフライ油でさし油な しに数 $\mathrm{kg}$ の揚げだねのディープフライが可能であるか ら，フライ油が $\mathrm{G} \geqq 10$ に褐変する十分な可能性がある

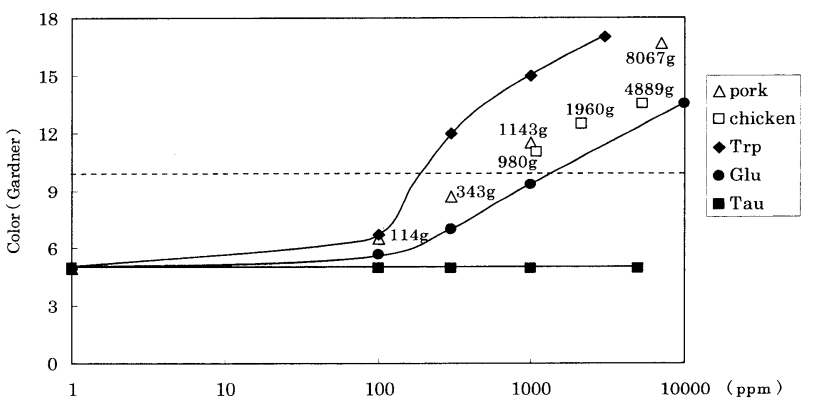

Fig. 2 Browning of Oil by Heating at $180^{\circ} \mathrm{C}$ for $20 \mathrm{~h}$ with Dried Juice from Frying Foodstuffs.

The number next to each symbol is the weight/L oil of the raw meat from which the juice was prepared. 
と判断された。これより揚げだねから漏出するアミノ酸 がフライ油の褐変を引き起こす原因の半分を占めると認 めた。

\section{3 劣化油の安全性}

前述のように調理済みフライの消費量が飛躍的に伸び ている現状から，そこに含まれるフライ油の安全性は健 康上無視できない。回収油は食品加工業において廃裹直 前までディープフライに使用されていたため，調理済み フライ製品が含む劣化したフライ油の代表として見なす ことができる。（再利用できない程度に劣化したフライ 油は燒却処理されているため，回収油は廃フライ油のう ち比較的劣化していないフライ油と考えられる。）

\section{$3 \cdot 1$ 回収油を用いた動物実験}

われわれは，ヒトの通常の摂食になぞらえて非常に穏 和な条件下で動物実験を実施した。すなわち，高血圧自 然発症・糖尿病・肥満モデルである SHR/NDmc-cp ラッ 卜 (雄性, 10 週齢 $)^{13)}$ と, 健康体モデルであるWistar ラット (雄性, 10 週齢 $)^{14)}$ に, AV 2.1, COV 10.3, PC $20.3 \%$, POV $16.5 \mathrm{meq} / \mathrm{kg}$ の性状をもつ回収油（ミョシ 油脂 B グレード植物回収油）7\% (実験群) あるいは新 鮮油 7\%（コントロール群）を混合した AIN $93 \mathrm{G}$ 無脂 肪食を 8 週間自由掑食させた。その間，下痢・皮脂漏 症・過度の脱毛などの外見的な異常は認められず，摂食 量 - 体重増加 - 粪量 - 血圧 - 心拍数においても実験群と コントロール群に有意差は現れなかった。しかし， $\mathrm{SHR} / \mathrm{NDmc}-\mathrm{cp}$ ラットの実験群において，血中のグル コース濃度とトリアシルグリセロール濃度, 遊離脂肪酸 濃度がコントロール群よりも有意に高く, リン脂質濃 度, 総コレステロール濃度も害験群が高い傾向を示し た。血中インスリン濃度には差が全く認められなかった (Table 2)。同様の傾向がWistar ラットにも見られた。 さらに肝臓と腎蔵の顕微鏡観察を行ったところ, $\mathrm{SHR} / \mathrm{NDmc}-\mathrm{cp}$ ラット実験群の腎尿細管の上皮細胞の染 色性が悪い上に，核の消失が多く見受けられた。また実 験群の肝臓は大滴性の脂肪の分布が不均一に減少してい
た。腎臓の顕微鏡観察においても，SHR/NDmc-cp ラッ トと同様の現象が Wistar ラットに認められた。以上ま とめると，回収油の摂取は外見上，健康被害を示さない が，血液組成に悪影響を与えるとともに腎臓を顕著に障 害させることが動物実験により示唆された。これらの現 象は生活習慣病発症に密接な関係があると思われる。回 収油レベルに劣化したフライ油の摂取頻度は $2 \cdot 1$ に述べ た通りである。2005 年の医療費は 30 兆円を超えてお り，そのうち生活習慣病関連の費用は $32 \%$ 占めた。 生活習慣病の主な原因のひとつは摂取栄養の量と質であ る。日本人は一日当たり平均 $10 \sim 15 \mathrm{~g}$ の油をフライな どから摂取しているので，掑取するフライ油の性状は生 活習慣病予防のための無視できない因子となると考えら れる。

\section{4 回収油の脱色}

廃食用油は工業廃油に比較してその劣化の程度が軽い ことより，膜分離技術を用いて廃食用油を精製し，食用 として再利用する研究が進められている ${ }^{15-18)}$ 。それにつ いては本特集の 1 件目に詳述されているため，ここでは 化学的方法により回収油を脱色して工業用途の油を再生 する方法について述べる。回収油の色相を低コストで $\mathrm{G}<6$ に改善するだけでも回収油の応用範囲は大きく広 がることが予想されている。脱色方法には吸着剤による 褐変物質の吸着除去・酸精製・アルカリ精製・還元・水 素添加・過酸化物による褐変物質の分解などが挙げられ る。

\section{$4 \cdot 1$ 回収油の脱色 ${ }^{19,20)}$}

フライ油のディープフライによる褐変は，フライ油自 体の加熱着色とアミノ・カルボニル反応生成物によるこ とが $2 \cdot 2$ で絞り込めたことより，回収油の脱色は一通り の化学的方法で達成可能ではないことが予想される。

色相 G6 を目標にして，これらの方法をまず実験室レ ベルで回収油（ミヨシ油脂 B グレード植物回収油）につ いて行った。回収油の性状は2.1の冒頭に示した通りで あった。検討した種々の脱色方法のうち比較的に実現の

Table 2 Hematological Values in SHR/NDmc-cp and Wistar Rats Fed a Diet Containing $7 \%$ Recovered Oil or Soybean Oil for 8 Weeks.

\begin{tabular}{l|c|c|c|c}
\hline \multirow{2}{*}{} & \multicolumn{2}{|c|}{ SHR/NDmc-cp rat } & \multicolumn{2}{c}{ Wistar rat } \\
\cline { 2 - 5 } & Recovered oil & Soybean oil & Recovered oil & Soybean oil \\
\hline Glucose (mg/dL) & $203.8 \pm 31.5^{*}$ & $152.5 \pm 32.2$ & $197.1 \pm 36.8$ & $172.8 \pm 30.2$ \\
Free fatty Acids (mg/dL) & $1.09 \pm 0.03^{*}$ & $0.98 \pm 0.08$ & $0.48 \pm 0.09$ & $0.52 \pm 0.08$ \\
Phospholipids (mg/dL) & $284.5 \pm 41.3$ & $254.9 \pm 43.8$ & $135.9 \pm 15.2^{*}$ & $112.1 \pm 10.8$ \\
Triacylglycerol (mg/dL) & $344.0 \pm 115.3^{*}$ & $195.2 \pm 97.1$ & $106.4 \pm 44.9$ & $71.5 \pm 26.1$ \\
Cholesterol (mg/dL) & $158.2 \pm 37.9$ & $149.5 \pm 24.1$ & $63.1 \pm 9.5$ & $58.8 \pm 5.8$ \\
Insulin (ng/mL) & $15.7 \pm 1.8$ & $15.9 \pm 2.3$ & $3.7 \pm 0.6$ & $4.0 \pm 1.8$ \\
\hline
\end{tabular}

Values are means \pm SD for six animals.

${ }^{*} \mathrm{p}<0.05$, significantly different from the value of the control group (unpaired t-test). 


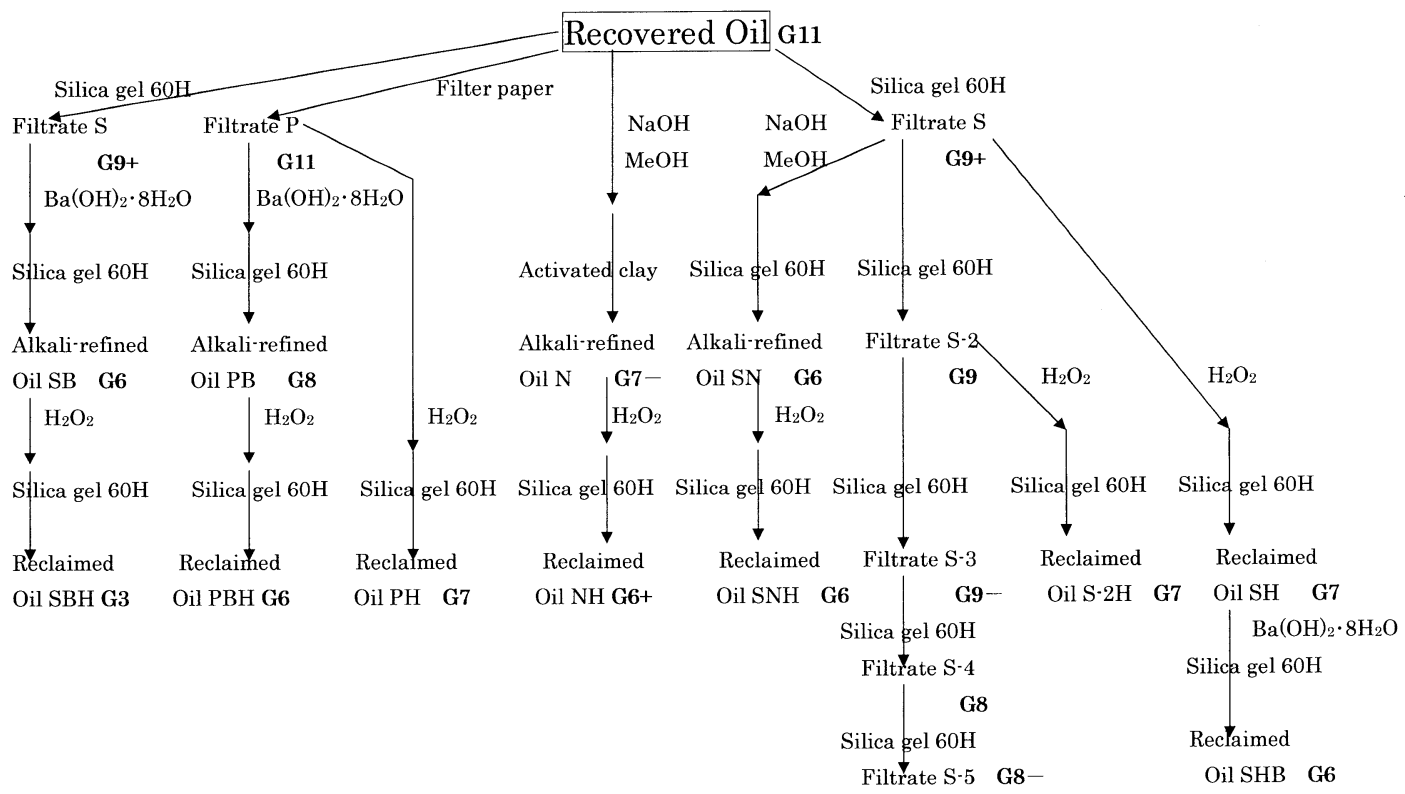

Fig. 3 Color Improvement of Recovered Oil. $\quad \mathrm{G}=$ Gardner color

可能性のある経路をFig. 3 に示した。回収油にシリカゲ ル $(2.0 \mathrm{wt} \%)$ ろ過を実施することは，回収油中の固形 物や水分，異臭を除去するために必須であったが，5回 繰り返してもさほど色相の改善はなく，大量の使用済み シリカゲルの廃棄の問題が浮上した。1回のろ過後, 過 酸化水素により脱色したが G 7 にしか到達しなかったた め，アルカリ処理を施した。種々のアルカリを検討した が，安全で汎用性のある $\mathrm{NaOH}$ 水溶液をろ過後の回収 油に添加混合する方法と，タンパクの精製などに使用さ れる $\mathrm{Ba}(\mathrm{OH})_{2} \cdot 8 \mathrm{H}_{2} \mathrm{O}$ 粉末を固体のまま，乃過後の回収 油に添加混合する方法を選択した。この操作による見か けの脱色効果は十分ではなかったが，さらに過酸化水素 処理をおこなったところ，目標に到達できた。とくに $\mathrm{Ba}(\mathrm{OH})_{2}$ を使用すると $\mathrm{G} 3$ にまで脱色することができ た。精製順序を変えてシリカゲルろ過後, 過酸化水素脱 色をし， $\mathrm{Ba}(\mathrm{OH})_{2}$ 処理をしても脱色効果が認められな かったことより, $\mathrm{Ba}(\mathrm{OH})_{2}$ 処理により着色物質が除去さ れやすくなることが推察された。Fig. 4 には脱色が進行 するに連れて 380～540 nm の吸収が急激に減少すること

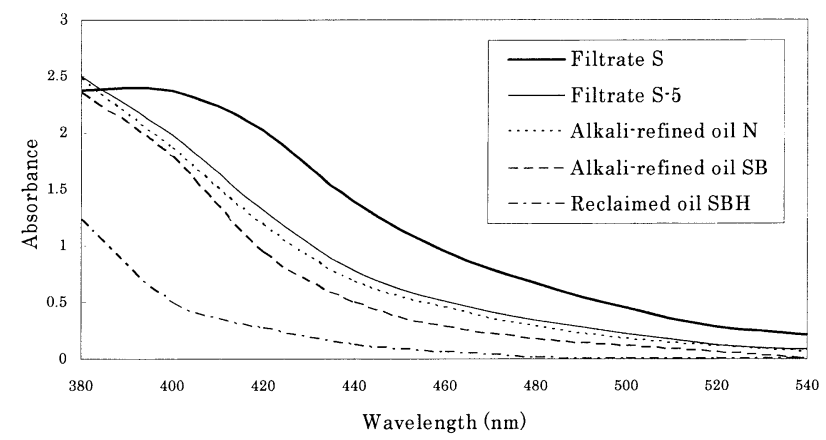

Fig. 4 Absorbance Spectra of Oils under Reclamation.
が示されている。短波長側の吸収は黄色に対応してお り, 非常に脱色しにくかった。黄色物質は極性の低い着 色物質であると考えられる。

実験室的に絞り込んだ脱色法をもとに，経済性・安全 性・操作性を考慮して方法を改良した（Fig. 5)。シリカ ゲルはガレオンアースに, $\mathrm{Ba}(\mathrm{OH})_{2} \cdot 8 \mathrm{H}_{2} \mathrm{O}$ 処理後のろ過 速度上昇のために水洗を加え, 油に少量残留している $\mathrm{Ba}(\mathrm{OH})_{2}$ を完全に除去するために希硫酸洗浄を加えた。

Recovered Oil Gardner color 11-12

filtered on 2.0 wt\% Galleon Earth $\mathrm{V}_{2} \mathrm{R}$

Filtrate Gardner color 10-10.5

agitated with $\mathrm{Ba}(\mathrm{OH})_{2} \cdot 8 \mathrm{H}_{2} \mathrm{O}$ at $70-80^{\circ} \mathrm{C}$

washed with 50 wt $\%$ water at $50^{\circ} \mathrm{C}, 4$ times

filtered on 2.0 wt\% Galleon Earth $\mathrm{V}_{2} \mathrm{R}$

Alkali-refined Oil GBW Gardner color 8-9

bleached by $5.0 \mathrm{wt} \%$ hydrogen peroxide for $60 \mathrm{~min}$ at $115-120^{\circ} \mathrm{C}$

washed with $50 \mathrm{wt} \% 3 \mathrm{M}$ sulfuric acid soln.

washed with water at $50^{\circ} \mathrm{C}$ until neutral

dried at $100^{\circ} \mathrm{C}$ under vacuum

filtered on $2.0 \mathrm{wt} \%$ Galleon Earth $\mathrm{V}_{2} \mathrm{R}$

Reclaimed Oil GBWHW Gardner color 5-6

Fig. 5 Proposed Method for Reclaiming Recovered Oil. 
得られた再生油は AV 1.9, 含水量 $0.1 \%, \mathrm{Ba}$ 含量 0.0 ppm， G 5 〜 6 の性状を示し， $200^{\circ} \mathrm{C}$ で $1 \mathrm{~h}$ 加熱しても $\mathrm{G}$ が 1 上昇しただけであったので加熱安定性も充分と思わ れた。しかし一層簡略でコストのかからない脱色方法が 望ましく，加えて極性の小さい化合物や重合物も同時に 除去可能な方法が見いだされれば申し分ない。回収油の ビジネスは，品質の良い劣化油の回収量・用途・価格， 精製コスト，再生油の市場等が複雑にからみあうため非 常に難しいと伝えられているが，環境問題や資源の不足 を考えた場合，その有効利用は決して忘れてはならない 課題である。

\section{$4 \cdot 2$ 脱色回収油の応用範囲}

$4 \cdot 1$ で脱色して得られた再生油は重合物・分解物・極 性物質を含んでいるため，食用には不適である。回収油 を加水分解やエステル交換を用いて精製することも十分 可能であり容易であるが，トリアシルグリセロールの構 造を残したまま脱色を試みた点が重要であり，脱色され た回収油はぺイントやインク等の用途に使用される場 合，色素配合等の加工における自由度が増すと考えられ る。

\section{5 フライ油の劣化防止}

劣化した油の有効利用に加えてフライ油の劣化防止方 法も同時に重要と考える。油脂あるいは食品に含まれる 油脂を常温で酸化させない方策としては，抗酸化剤の添 加・空気の窒素置換 - 減圧 ·包装材料の工夫 ・ 油脂の使 用量減少・安定な脂肪酸の利用などがあるが，フライ油
の場合にディープフライの最中の加熱酸化と揚げ物が摂 食されるまでの保存中の酸化の問題がある。抗酸化剤は 加熱されると効果を失いやすいので，保存中の抗酸化効 果もあまり望めない。ディープフライをせずに油脂を噴 霧した食材をオーブンで加熱することによりディープフ ライと同様の仕上がりを期待する冷凍食品もあるが，熱 供給速度が圧倒的に小さいために仕上がり時の食感が異 なる等の理由により，日本国内では多用されていないと 思われる。

\section{$5 \cdot 1$ 抗酸化剤の効果}

これまでに油脂の抗酸化剂の効果に関する多数の報告 がある。ジャガイモをデイープフライするとき，カノー ラ油に $\alpha$-トコフェロールや ascorbyl palmitate を添加 ${ }^{21)}$ あるいは，トリオレインに $\gamma$ ートコフェロールを添加し た ${ }^{22)}$ 場合，抗酸化剤は数時間，その効果を保持すること が報告されている。一方，オリーブ油 ${ }^{23,24)}$ やヒマワリ油 ${ }^{24)}$ 中の天然抗酸化剂もディープフライ開始数時間後に，効 果が消失することが報告されている。

$2 \cdot 2$ のモデル実験においてフライ油の着色は酸化反応 を反映していることより， $\alpha$-トコフェロール， BHT， レシチンを各々フライ油に添加して色相の変化を観察し たところ，加熱 $5 \mathrm{~h}$ でわずかに着色が抑制されたが， 10 $\mathrm{h}$ 以降にはまったく抗酸化剂の効果は認められなかっ た ${ }^{25)}$ 。前述した通り，一般家庭でのディープフライで は，1バッチのフライ油を数回しか使用しないため, 油 の酸化毒性は問題が少ないが, 食品加工業では見かけ $20 \mathrm{~h}$ フライ油を $180^{\circ} \mathrm{C}$ 加熱しフライ製造に使用してい
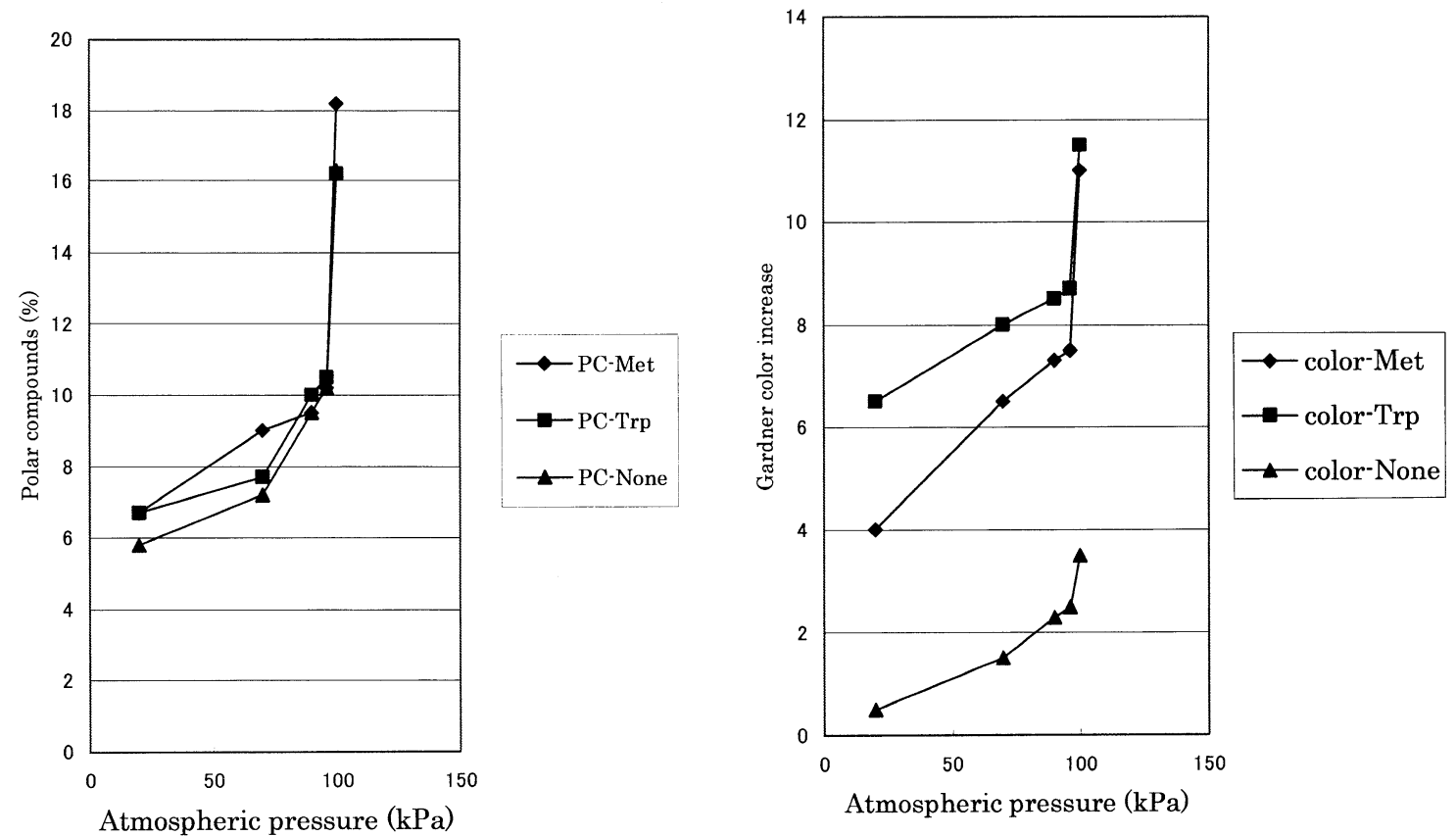

Fig. 6 Atmospheric Pressure, Polar Compounds, and Oil Color. 
るため，これまでのいずれの抗酸化剂もあまり有效でな いと考えられる。

\section{$5 \cdot 2$ 酸素供給減少の効果 ${ }^{25)}$}

$2 \cdot 2$ のフライモデル実験を種々の減圧下で行った (Fig. 6)。フライ油の色相変化は個々のアミノ酸の発色 係数の違いにより大小の差異はあったが, わずかな空気 圧の低下，すなわち $100 \mathrm{kPa}$ から $97 \mathrm{kPa} に$ 減圧するだ けで褐変はガードナースケールで約半分になった。さら に減圧を高めると一層褐変が抑えられた。このときの極 性化合物量を測定するとアミノ酸の種類やアミノ酸の添 加の有無に関わらず，97 kPa に減圧するだけで急激に減 少していた。減圧の上昇に伴う極性化合物量の減少も色 相と同様の傾向を示した。このように酸素の供給をわず かに抑制するだけで油への酸素の溶解は激減し, すでに フライ油中に溶存していた酸素による油の酸化が主に進 行したと考えられる。上述のように, 現時点でフライ時 に長時間効果的な抗酸化剂は見出されていないが, 酸素 の供給をわずかに制限するだけで大幅に加熱酸化が抑制 できるため, 食品加工業においてこの知見が応用される ことが望まれる。

\section{6 おわりに}

世界中で，日本人が食材の新鮮さを一番重要視するの ではないかと思われる。その日本にあって調理済み惣菜 に含まれる油，とくにフライ油の性状の実態は必ずしも 完璧ではなく, 生活習慣病との関連も示唆されてい $3^{6-10,13.14)}$ 。食品加工業でのフライ油の使用時間を短縮 することにより調理済みフライの品質が向上し, 廃食用 油の品質も向上して, 廃食用油の主な用途である動物飼 料（養鵎每 ${ }^{2-28)}$ ・養豚 ${ }^{29-33)}$ など）に配合される油脂の性状 も改善される。このような食物連鎖を考えたとき, ヒト の健康にどのような効果がもたらされるのか興味が持た れる。また劣化フライ油摂取により健康が損なわれるこ とが確実となれば，それに係わる医療費や，廃油の焼却 等による環境污染の防止に今後必要となる対策費までを 含めた全コストを考えた時, われわれが現在よりも劣化 していないフライ油を摂取するほうが，それによるフラ イ油のコスト上昇よりも結果的に経済的であるという推 論も可能となるのではなかろうか。そして, 極端に劣化 して再利用の可能性のない回収油はなくなり, 回収油量 と回収油消費量のバランスがとれるように回収油の用途 拡大を図ることにより, 廃油による環境污染は確実に減 少すると考えられる。

\section{謝 辞}

回収油ならびにそれに関連する多くの情報を快く提供
していただき，また本テーマに対して研究費の提供をし ていただきましたミヨシ油脂株式会社に深謝いたします。

\section{文献}

1) Japan Oil Industry Almanac, 2003 (8), P.88.

2) 薄木理一郎, 油化学, 42, 885-92 (1993).

3) N. Totani, K. Iwanaga, M. Takada, O. Takeda, M. Furuta, M. Moriya, A. Yamaguchi \& T. Ueda, J. Oleo Sci., 53, 221-9 (2004).

4) 油脂, 57, 20 (2004).

5) N. Totani, T. Ohno \& A. Yamaguchi, J. Oleo Sci., 55 (9), 449-56 (2006).

6) F. Soriguer, G. Rojo-Martinez, M.C. Dobarganes, J.M. Garcia-Almeida, I. Esteva, M. Beltran, M.S. Ruiz De Adana, F. Tinahones, J.M. Gomez-Zumaquero, E. Garcia-Fuentes \& S. Gonzalez-Romero, Am. J. Clin. Nutr., 78, 1092-7 (2003).

7) J.Rosen \& K. Hellenaes, The Analyst, 27, 880-2 (2002).

8) E. Tareke, P. Rydberg, P. Karlsson, S. Eriksson \& M. Toenqvist, J. Agric. Food Chem., 50, 4998-5006 (2002).

9) D.S. Mottram, B.L. Wedzicha \& A.T. Dodson, Nature, 419, 448-9 (2002).

10) R.H. Stadler, I. Blank, N. Varga, F. Robert, J. Hau, P.A. Guy, M. Robert \& S. Riediker, Nature, 419, 449 (2002).

11) N. Totani, A. Yamaguchi, M. Takada \& M. Moriya, J. Oleo Sci., 55, 51-7 (2006).

12) N. Totani, T. Kuzume \& A. Yamaguchi, J. Oleo Sci., 55 (9), 441-7 (2006).

13) N. Totani, K. Satoh, S. Tsuji \& A. Yamaguchi, J. Oleo Sci., 55, 283-9 (2006).

14) N. Totani, K. Satoh, S. Tsuji \& A. Yamaguchi, J. Oleo Sci., 55, 291-7 (2006).

15) J.B. Snape \& M. Nakajima, J. Food Eng., 30, 1-41 (1996).

16) R. Subramanian, M. Nakajima \& T. Kawakatsu, J. Food Eng., 38, 31-56 (1998).

17) A. Miyagi, M. Nakajima \& H. Nabetani, J. Jpn. Oil Chem. Soc., 49, 237-44 (2000).

18) A. Miyagi, R. Subramanian \& M. Nakajima, J. Am. Oil Chem. Soc., 80, 927-932 (2003).

19）岩永和人, 武田宰, 高田満信, 古田光紀, 守屋雅文, 戸谷永生, 山口彩子, 上田隆史, 日本化学会第 84 回年 会講演要旨「廃食用油の再生」(2004).

20) N. Totani, K. Iwanaga, M. Takada, O. Takeda, M. Furuta, M. Moriya, M. Yawata, A. Yamaguchi \& T. Ueda, J. Jpn. Oil Chem. Soc., 54, 63-70 (2005).

21) B. Onal \& G. Ergin, Nahrung, 46, 420-3 (2002).

22) K. Warner, W.E. Neff \& F.J. Eller, J.Agric. Food Chem., 51, 623-7 (2003).

23) S. Gomez-Alonso, G. Fregapane, M.D. Salvador \& M.H. Gordon, J.Agric. Food Chem., 51, 667-72 (2003).

24) N.K. Andrikopoulos, G.V. Dedoussis, A. Falirea, N. Kalogeropoulos \& H.S. Hatzinikola, J. Food Sci. Nutr., 53, 351-63 (2002).

25) N. Totani, J. Oleo Sci., 55, 135-41 (2006).

26) R. Bou, R.C. Tres, M.D. Baucels \& F. Guardiola, Poult. Sci., 84, 1942-54 (2005). 
27) P.J. Sheehy, P.A. Morrissey \& A. Flynn, Br. J. Nutr., 71, 53-65 (1994).

28) R. Bou, R. Codony, M.D. Baucells \& F. Guardiola, J. Agric. Food Chem., 53, 7792-801 (2005).

29) J.P. Suomela, M. Ahotupa \& H. Kallio, Lipids, 40, 437-44 (2005).

30) J.P. Suomela, M. Ahotupa, O. Sjoevall, J.P. Kurvinen \& H.
Kallio, Lipids, 39, 639-47 (2004).

31) J.F. Liu \& F.C. Chan, J. Nutr. Sci. Vitaminol. (Tokyo), 46, 240-5 (2000).

32) K. Eder \& G.I. Stangl, J. Nutr., 130, 116-21 (2000).

33) L. Ozimek, R. Mosenthin \& W.C. Sauer, Z. Ernahrungswiss., 34, 224-30 (1995). 